\title{
Latex Foam Mattresses for Hospitals
}

\author{
A RECORDED VOLUNTARY STANDARD OF THE TRADE
}

\section{COMMODITY STANDARDS}

Simplified Practice Recommendations and Commercial Standards are developed by manufacturers, distributors, and users in cooperation with the Commodity Standards Division of the Office of Industry and Commerce, Bureau of Foreign and Domestic Commerce, and with the National Bureau of Standards.

The purpose of Simplified Practice Recommendations is to eliminate avoidable waste through the establishment of standards of practice for stock sizes and varieties of specific commodities that currently are in general production and demand. The purpose of Commercial Standards is to establish standard methods of test, rating, certification, and labeling of commodities, and to provide uniform bases for fair competition.

The adoption and use of a Simplified Practice Recommendation or a Commercial Standard is voluntary. However, when reference to a Commercial Standard is made in contracts, labels, invoices, or advertising literature, the provisions of the standard are enforceable through usual legal channels as a part of the sales contract.

A Simplified Practice Recommendation or a Commercial Standard originates with the proponent industry. The sponsors may be manufacturers, distributors, or users of the specific product. One of these three elements of industry submits to the Commodity Standards Division the necessary data to be used as the basis for developing a standard of practice. The Division, by means of assembled conferences or letter referenda, or both, assists the sponsor group in arriving at a tentative standard of practice and thereafter refers it to the other elements of the same industry for approval or for constructive criticism that will be helpful in making any necessary adjustments. The regular procedure of the Division assures continuous servicing of each effective Simplified Practice Recommendation and Commercial Standard, through review and revision, whenever, in the opinion of the industry, changing conditions warrant such action. Simplified Practice Recommendations and Commercial Standards are printed and made available by the Department of Commerce through the Government Printing Office and the Department of Commerce field offices.

\section{UNITED STATES DEPARTMENT OF COMMERCE}

\section{Charles Sawyer, Secretary}




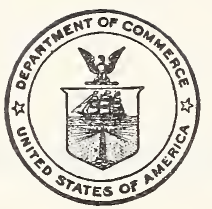

U. S. DEPARTMENT OF COMMERCE

Charles Sawyer, Secretary

BUREAU OF FOREIGN AND DOMESTIC COMMERCE

Office of Industry and Commerce

H. B. McCoy, Director

IN COOPERATION WITH

NATIONAL BUREAU OF STANDARDS

A. V. ASTIN, ACTING DIRECTOR 


\title{
Latex Foam Mattresses for Hospitals
}

\author{
[Effective October 10, 1951]
}

\section{PURPOSE}

1.1 The purpose of this commercial standard is to provide a nationally recognized standard for latex foam mattresses; to promote fair competition among manufacturers and protect purchasers against inferior products; and to provide a basis for guaranteeing quality.

\section{SCOPE}

2.1 This standard covers sizes, minimum requirements, and methods of testing for one grade of latex foam mattresses for hospitals, which may be manufactured from either natural or synthetic types of rubber latex. It also includes a recommended method of labeling to be used by the manufacturer.

\section{SIZES}

3.1 Sizes of finished mattresses shall be as specified, within the tolerances shown in table 1 , page 3 . When the bed size is specified, mattresses shall be finished 1 in. shorter and 1 in. narrower, within the indicated tolerances. Latex foam unit shall be 1 in. larger in each lateral dimension than the covered mattress.

\section{REQUIREMENTS}

4.1 Workmanship.-The workmanship shall be first class in every respect and the mattress shall be free from imperfections in manufacture which might affect either its appearance or serviceability. The mattress shall readily conform to any position of the multiple-position bed spring without any injury to the mattress. Molded or assembled shapes which, due to manufacturing conditions, may have to be altered physically will be accepted under this specification, providing that such alteration does not affect the serviceability, or size or shape beyond the tolerances as specified herein. The material used in such repair or alteration shall be of the identical composition and quality as the original product.

4.2 Materials.-Ail materials shall be 100 percent new materials.

4.3 Latex foam unit.

4.3.1 The latex foam shall conform to the best commercial quality of this type of product and shall meet the requirements as designated herein. 
4.3.2 Structure.-The latex foam unit shall be made in not more than four sections, cemented in a manner that the seams shall not be so firm as to be detectable through the cover, and shall consist of interconnecting cells, permeable to air and water, reasonably uniform in size and free from unrepaired surface voids of $5 / 8$ in. or larger. End or side walls may be added to adjust for size, not to exceed $11 / 2$ in. on any one wall.

4.3.3 Side-wall thickness.

4.3.3.1 Straight-row lug spacing: Wall thickness shall be $13 / 4$ in. minimum with permissible use of one additional row of lugs $1 / 2$ in. or less in diameter. This row, if used, to be a minimum of 1 in. from the edge.

4.3.3.2 Staggered-row lug spacing: Average minimum wall thickness shall be $11 / 2$ in.; 1 in. minimum wall thickness for closest lugs.

4.4 Inner cover (optional).-The latex unit may be enclosed in a muslin cover meeting the following minimum requirements:

Weight ........2. oz/sq. yd.

Thread count ......48 by 48 .

Breaking strength ...Warp, 35 lb/in.; filler, 25 lb/in.

Thread for stitching. . Breaking strength, $3 \mathrm{lb}$. Stitches .........10/in.

\subsection{Cover.}

4.5.1 Ticking or cover (optional).-High-grade blue and white twill, or other suitable weave ticking having not less than 78 warp threads and 62 filling threads per inch, and weighing not less than $9 \mathrm{oz} / \mathrm{sq}$. yd. (equivalent to $8 \mathrm{oz} / \mathrm{lin}$. yd., $32 \mathrm{in}$. wide), shall be used. Breaking strength (grab method) shall be not less than $135 \mathrm{lb}$. warp and $90 \mathrm{lb}$. filling, or not less than $115 \mathrm{lb}$. in both warp and filling. Residual shrinkage shall not exceed 2 percent.

4.5.1.1 The ticking on each face or cover shall be made of not more than one piece. The stripes of the ticking on the upper and lower faces shall run lengthwise.

4.5.1.2 The cover shall be removable and closed at the side or end panel with either laundry-proof snap fasteners or slide fasteners. The snap fasteners shall be spaced not more than $10 \mathrm{in}$. apart.

4.5.2 Thread and stitching.-Thread shall be not less than 3-cord and shall have a breaking strength (single strand) of not less than $3 \mathrm{lb}$. All machine stitching shall run not less than 10 stitches to the inch.

4.6 Lifting straps.-Two lifting straps of double-thickness ticking, with turned-in sewed edges, not less than $1 / 2$ in. wide, shall be securely attached in a vertical position to each side of the mattress border at the top and bottom seams, located about 36 in. apart and equidistant from the ends. Straps will not be required on mattresses 60 in. or less in length. When longitudinal lifting straps are specified in lieu of vertical, they shall be furnished only on prebuilt borders or when other adequate reinforcement is provided. 
4.7 Odor.-The mattress shall be free from any objectionable odor.

4.8 Tags.-Tags marked to conform to the legal requirements of the State in which the mattress was manufactured and/or is to be sold shall be sewed on each mattress cover.

4.9 Each foam rubber unit shall be permanently marked with the manufacturer's name or recognized trade-mark.

4.10 Accelerated aging.

4.10.1 Maximum change in indentation from the original value, as measured in paragraph 4.16 , shall be \pm 20 percent, after treating in the air oven as described in paragraph 5.1.1.

4.10.2 Air-bomb effect.-A specimen cut from the mattress shall not change shape, become hard, soft, or appreciably tacky when subjected to the air-bomb test described in paragraph 5.1.2.

4.11 Maximum permanent set shall be 10 percent of the original height of the sample when tested according to paragraph 5.2.

4.12 Flexing.-A sample of the mattress, at least $12 \mathrm{in.} \mathrm{by}$ 12 in., taken from the softest section of the mattress, shall withstand a minimum flexing of 250,000 cycles, as described in paragraph 5.3, without showing any breakdown of the physical structure, or permanent set greater than 10 percent. For mattresses of variable core construction, the sample shall be taken from the softest area.

4.13 Washability.-The mattress shall be capable of being washed repeatedly, without damage, in a hot $\left(150^{\circ}\right.$ to $\left.160^{\circ} \mathrm{F}\right)$ 1-percent soap solution conforming to Federal Specification P-S-616.

4.14 Dimensional tolerances.-Tolerances on length and width of latex foam units without cover shall be as shown in table 1 .

TABle 1. Dimensional tolerances

\begin{tabular}{|c|c|c|}
\hline \multirow{2}{*}{ Nominal length or width (in.) } & \multicolumn{2}{|c|}{ Tolerance } \\
\hline & Plus & Minus \\
\hline $\begin{array}{l}0 \text { to } 6 \text { - } \\
6 \text { to } 12-12 \\
12 \text { to } 24 \\
24 \text { to } 36 \\
36 \text { to } 48 \\
48 \text { to } 60 \\
60 \\
72 \text { to } 72 \text { and over }\end{array}$ & in. $\begin{array}{l}3 / 16 \\
3 / 8 \\
112 \\
5 / 8 \\
3 / 4 \\
7 / 8 \\
11 / 8 \\
1 / 8\end{array}$ & 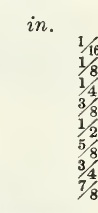 \\
\hline
\end{tabular}

4.15 Thickness.-Four-and-one-half-inch mattresses (without cover) shall be $41 / 2$ in. thick at the crown, with a maximum crown of $1 / 2$ in., and with a plus tolerance of $3 / 16$ in. and a minus tolerance of $1 / 8$ in. Three-inch mattresses (without cover) shall be 3 in. thick at the box, within the foregoing tolerances, and 3 in. thick throughout, minimum. Crown is not required on threeinch mattresses, but is permitted at the manufacturer's discretion. Two-and-one-half-inch mattresses (supplied only in crib sizes) shall be $21 / 2$ in. thick (without cover), with a plus tolerance of $1 / 8$ in. and a minus tolerance of $1 / 16 \mathrm{in}$.; they are normally supplied without a crown, but may be moderately crowned at the 
discretion of the manufacturer. Care not to distort latex foam shall be observed in making measurements.

4.16 Indentation or compression.-The load, in pounds, required to compress the mattress 25 percent of its thickness, using an indentor foot $50 \mathrm{sq}$. in. in area, shall be determined as described in paragraph 5.4. The compression resistance shall be $28.5 \pm 6.5 \mathrm{lb}$. $(0.57 \pm 0.13 \mathrm{lb} / \mathrm{sq}$. in.).

4.17 Static fatigue.-The latex foam shall show no cracking at the folded edge when tested in accordance with paragraph 5.5.

4.18 Packing.--This specification contemplates that mattresses normally will be shipped by closed truck, unmixed with other freight and protected from injury, direct from bidder's plant or warehouse to the purchaser. For such methods of shipment, cartons will not be required except when specified in invitations for bids. Mattresses shipped by less-than-carload-lot freight, or by truck in mixed cargo shall be packed in fiberboard or cardboard cartons.

\section{METHODS OF TEST}

\subsection{Accelerated aging.}

5.1.1 Air-oven test.-The conditions described in paragraphs $14 \mathrm{~b}$ and $14 \mathrm{c}$ of Federal Specification ZZ-R-601a shall apply excepting that the test shall be run for 22 hours at $212^{\circ} \mathrm{F}$. The specimen used shall be at least 12 in. by 12 in.

5.1.2 Air-bomb test.-The conditions described in paragraphs $14 \mathrm{~b}$ and $14 \mathrm{c}$ of Federal Specification ZZ-R-601a shall apply excepting that the test shall be run for 2 hours at $260^{\circ} \mathrm{F}$ and $60 \mathrm{lb} / \mathrm{sq}$ in. pressure. The specimen used shall be a plug approximately $1 / 2$ in. in diameter and at least $1 / 2$ in. long.

5.2 Permanent set under constant deflection. - The sample shall be compressed to 50 percent of its height for 22 hours at $158^{\circ} \mathrm{F}$. The load shall be released at the end of the test period and the thickness measured after 30 minutes rest at room temperature.

5.3 Flexing.-The 12-in. by 12-in. sample shall be compressed to 50 percent of its original thickness at a rate of 60 cycles per minute, and shall be placed on a perforated base during flexing to allow escape of air. The sample shall have parallel upper and lower surfaces and shall represent the entire cushioning unit where possible. The foot of the compressor unit shall be flat, parallel to the base, and in all cases shall be larger than the sample.

5.4 Indentation or compression test.-A suitable instrument shall be provided to measure the load, to the nearest pound, necessary to produce an indentation into the mattress of 25 percent of its thickness. There shall be provided a circular indentor foot with square edges, of $50 \mathrm{sq}$. in. in area, connected by a ball-and-socket joint to a load-measuring device (such as a scale), and mounted in such a manner that the specimen can be depressed at a rate of 25 in. per minute. The cored side of the mattress, if any, should be placed on a plate which has been drilled with $1 / 4$-in. holes on $3 / 4$-in. centers to allow for rapid escape of air. The specimens, if cutout sections, shall be not less than 12 by 12 in. The test shall be made with the indentor foot in the center of a cutout section, and 
in no event shall it be made within $4 \mathrm{in}$. of the edge of the mattress. Tests shall be made at the center and 12 in. from one end, and the loads averaged. The result obtained in this test is influenced by temperature and humidity conditions, and tests which are to be compared shall be conducted under substantially the same conditions.

5.4.1 In cases of dispute, the compression readings shall be performed at a temperature of $73.4^{\circ} \pm 2^{\circ} \mathrm{F}$, and in an atmosphere having a relative humidity of 50 percent \pm 4 percent. The product shall be conditioned undeflected and undistorted at this temperature and humidity for at least 12 hours before being tested. Ordinarily only one test shall be made but in cases of dispute the result shall be expressed as the average of a minimum of three tests.

5.5 Static fatigue.-Bend a piece of latex foam 4 in. by 9 in. ${ }^{1}$ parallel to the 4 -in. dimension to an angle of $180^{\circ}$ between two compression plates, and place in a Geer oven at $158^{\circ} \mathrm{F}$ for 22 hours. The opening between the two plates should be equal to twice the thickness of the unfolded sample. The folded edge of sample should not extend beyond the edges of the compression plate. When cored stock is tested, the core should be folded in.

\section{IDENTIFICATION}

6.1 In order that purchasers may be assured that latex foam mattresses purchased actually comply with all requirements of this commercial standard, it is recommended that manufacturers include the following statement in conjunction with their name and address on labels, invoices, sales literature, etc.:

This ...........type latex foam mattress complies (natural or synthetic)

with Commercial Standard CS182-51, as developed by the trade under the procedure of the Commodity Standards Division, and issued by the U. S. Department of Commerce.

6.2 When available space on labels is insufficient for the full statement in legible type, an abbreviated statement, as follows, is recommended:

Complies with CS182-51, as developed by the trade, and issued by the U. S. Department of Commerce.

\section{EFFECTIVE DATE}

7.1 Having been passed through the regular procedure of the Commodity Standards Division, and approved by the acceptors hereinafter listed, this commercial standard was issued by the United States Department of Commerce, effective from October 10, 1951.

EDWIN W. ELY, Chief, Commodity Standards Division.

1 This size is recommended for samples not more than 3 in. thick. For thicker samples, the 9-in. dimension should be increased to approximately three times the thickness. 
Under date of May 21, 1946, the American Hospital Association requested the cooperation of the National Bureau of Standards in the establishment of a commercial standard for latex foam mattresses for hospitals. The request was brought to the attention of the Rubber Manufacturers Association, and a technical committee of that association undertook the preparation of a specification to serve as a tentative draft of a proposed commercial standard.

On February 12, 1947, a tentative draft submitted by the Rubber Manufacturers Association was mailed to 162 producers, distributors, and users of mattresses for comment. Constructive comments were received and the tentative draft was modified in accordance with the consensus, through meetings and correspondence between the Division of Trade Standards of the National Bureau of Standards, the Rubber Manufacturers Association, and the American Hospital Association.

On February 17, 1950, a meeting of representatives of the Rubber Manufacturers Association, the American Hospital Association, and several governmental agencies was held at the National Bureau of Standards for final adjustment of the draft. A few provisions of the specification required additional investigation, and the adjustment of those provisions was conducted through correspondence. The proposed commercial standard, as finally adjusted, was approved by the American Hospital Association. On April 25, 1951, the approved draft was circulated as a recommended commercial standard to the entire industry for written acceptance; and on September 10 the Commodity Standards Division announced that sufficient acceptances had been received and that the commercial standard, to be designated CS182-51, would become effective from October 10, 1951.

Project Manager: F. W. Reynolds, Commodity Standards Division, Office of Industry and Commerce.

Technical Adviser: Dr. Norman P. Bekkedahl, Organic and Fibrous Materials Division, National Bureau of Standards.

\section{STANDING COMMITTEE}

The following individuals comprise the membership of the standing committee, which is to review, prior to circulation for acceptance, revisions proposed to keep the standard abreast of progress. Comment concerning the standard and suggestions for revision may be addressed to any member of the committee or to the Commodity Standards Division, Office of Industry and Commerce, U. S. Department of Commerce, which acts as secretary for the committee.

L. Schnuelle, Hewitt-Robins, Inc., Buffalo, N. Y. (Chairman.)

G. H. BARNES, Goodyear Tire \& Rubber Co., Inc., Akron, Ohio.

C. W. BrodT, Firestone Tire \& Rubber Co., Fall River, Mass.

E. C. Svendsen, United States Rubber Co., Mishawaka, Ind.

Leonard P. Goudy, American Hospital Association, 18 East Division St., Chicago 10, Ill. 
Dewey Palmer, Hospital Bureau of Standards \& Supplies, 247 Park Ave., New York 17, N. Y.

Allen Mathewson, Massachusetts General Hospital, Boston 14, Mass.

Neal Johnson, Johns Hopkins Hospital, Baltimore, Md.

\section{APPENDIX}

\section{Care of Latex Foam Mattresses}

A latex foam mattress is porous and should, therefore, like any other mattress, be protected from contaminating liquids.

If it is necessary to remove the latex foam unit from the cover, it should be protected against direct sunlight, which will cause deterioration.

While the rubber foam itself has sufficient tensile strength to withstand ordinary abuse, it can nevertheless be torn by mishandling. Therefore, some care must be taken in handling the product when it has been removed from the cover.

The following materials are harmless to latex foam rubber: ammonia water, borax, washing soda, soap solution, and synthetic detergents. Any other cleaning agent should be investigated thoroughly before using. Typical cleaning agents that are harmful include gasoline, carbon tetrachloride, bleaching solutions, and any acid material.

For sterilization, the mattress may be sprayed, sponged, or soaked with a mild antiseptic solution, such as Lysol or formaldehyde. It should not be subjected to temperatures above $150^{\circ} \mathrm{F}$ for a prolonged period of time and never to steam pressure. Any copper or manganese-bearing material should be avoided. 


\section{ACCEPTORS}

The organizations listed below have individually accepted this standard for use as far as practicable in the production, distribution, testing, purchase, or use of latex foam mattresses for hospitals. In accepting the standard they reserved the right to depart from it as they individually deem advisable. It is expected that mattresses which actually comply with the requirements of this standard in all respects will be regularly identified or labeled as conforming thereto, and that purchasers will require such specific evidence of conformity.

\section{ASSOCIATIONS}

(General Support)

American Hospital Association, Chicago, Ill. American Surgical Trade Association, Huntington, W. Va.

Cleveland Hospital Council, Cleveland, Ohio.

\section{HOSPITALS, FIRMS, AND} OTHER INTERESTS

Abington Memorial Hospital, Abington, $\mathrm{Pa}$. Allentown Hospital Association, Allentown, $\mathrm{Pa}$.

Altoona Hospital, Altoona, $\mathrm{Pa}$.

Arlington Hospital, Arlington, Va.

Ashland State Hospital, Ashland, $\mathrm{Pa}$.

Baltimore City Hospitals, Baltimore, Md.

Baltimore, City of, City Purchasing Agent, Baltimore, Md.

Barlow Sanatorium Association, Los Angeles, Calif.

Barnard Free Skin and Cancer Hospital, St. Louis, Mo.

Baroness Erlanger Hospital, Chattanooga, Tenn.

Beloit Municipal Hospital, Beloit, Wis.

Berea College Hospital, Berea, Ky.

Beth Israel Hospital, Boston, Mass.

Beth Israel Hospital, New York, N. Y.

Bethesda Hospital, Cincinnati, Ohio.

Bledsoe Memorial Hospital, Pikeville, Tenn.

Blodgett Memorial Hospital, Grand Rapids, Mich.

Bloomsburg Hospital, Bloomsburg, $\mathrm{Pa}$.

Blossburg State Hospital, Blossburg, Pa.

Boston Dispensary, Boston, Mass.

Boulder Sanitarium \& Hospital, Boulder, Colo.

Braddock General Hospital, Braddock, Pa.

Brodstone Memorial Hospital, Superior, Nebr.

Bronx Hospital, Bronx, New York, N.' Y.

Brooklyn Hospital, Brooklyn, N. Y.

Brooks Memorial Hospital, Dunkirk, N. Y.

Bryn Mawr Hospital, Bryn Mawr, Pa.

Buffalo General Hospital, Buffalo, N. Y.

Burbank Hospital, Fitchburg, Mass.

Burton-Dixie Corp., Chicago, Ill.

California Hospital, Los Angeles, Calif.

Carney Hospital, South Boston, Mass.

Central Dispensary and Emergency Hospital, Washington, D. C.

Central of Georgia Railway Co., Savannah, Ga.

Central Maine General Hospital, Lewiston, Maine.

Central Maine Sanatorium, Fairfield, Maine.

Central State Hospital, Petersburg, Va.

Charles S. Wilson Memorial Hospital, Johnson City, N. Y.

Chelsea Memorial Hospital, Chelsea, Mass.

Chestnut Hill Hospital, Philadelphia, Pa.

Chicago (Ill.), University of Chicago Clinics. Children's Hospital, Columbus, Ohio.

Children's Hospital, San Francisco, Calif.
Children's Hospital of the District of Columbia, Washington, D. C.

Children's Hospital, Inc., St. Paul, Minn.

Children's Hospital of Philadelphia, Philadelphia, $\mathrm{Pa}$.

Children's Hospital of Pittsburgh, Pittsburgh, $\mathrm{Pa}$.

Christ Hospital, Cincinnati, Ohio.

City Infirmary, St. Louis, Mo.

City Memorial Hospital, Winston-Salem, N. C.

Clearfield Hospital, Clearfield, $\mathrm{Pa}$.

Coaldale State Hospital, Coaldale, $\mathrm{Pa}$.

Colorado State Hospital, Pueblo, Colo.

Columbia Hospital, Astoria, Oreg.

Columbia Memorial Hospital, Hudson, N. Y.

Community Hospital, Berea, Ohio.

Community Hospital, Geneva, Ill.

Community Hospital, Kane, Pa.

Continental Hospital Service, Inc., Cleveland (Lakewood), Ohio.

Copper Country Sanatorium, Houghton, Mich. Cortland County Hospital Association, Cortland, N. Y.

Crouse-Irving Hospital, Syracuse, N. Y.

Cumberland Medical Center, Crossville, Tenn.

D. T. Watson Home for Crippled Children, Leetsdale, $\mathrm{Pa}$.

Delaware State Hospital, Farnhurst, Del.

Denver General Hospital, Denver, Colo.

Detroit Tuberculosis Sanatorium, Detroit, Mich.

Dixie Hospital, Hampton, Va.

Dunlop Tire \& Rubber Corp., Buffalo, N. Y.

Duval Medical Center, Jacksonville, Fla.

East Orange General Hospital, East Orange, N. J.

Easton Hospital, Easton, Pa.

Edward Sanatorium, Naperville, Ill.

Eichenlaub's, Pittsburgh, $\mathrm{Pa}$.

Electrical Testing Laboratories, Inc., New York, N. Y.

Emanuel Hospital, Portland, Oreg.

Emerald-Hodgson Hospital, Sewanee, Tenn.

Emergency Hospital, Buffalo, N. Y.

Essex County Sanatorium, Verona, N. J.

Evanston Hospital Association, Evanston, Ill.

Fairview Park Hospital, Cleveland, Ohio.

Faxton Hospital, Utica, N. Y.

Federation of Jewish Philanthropies of New York, New York, N. Y.

Ferry Machine Co., Kent, Ohio.

Firestone Industrial Products Co., Akron, Ohio.

Fitzgerald-Mercy Hospital, Darby, Pa.

Florida State Improvement Commission, Tallahassee, Fla.

Fort Wayne Methodist Hospital, Fort Wayne, Ind.

Franklin County Public Hospital, Greenfield, Mass.

General Hospital, Bluefield, W. Va.

Genesee Hospital, Rochester, N. Y.

Georgia Warm Springs Foundation, Warm Springs, Ga.

Gifford Memorial Hospital, Inc., Randolph, $\mathrm{Vt}$. 
Goodyear Tire \& Rubber Co., The, Akron, Ohio. Grace Hospital, Cleveland, Ohio.

Grandview Hospital, La Crosse, Wis.

Grant Hospital, Columbus, Ohio.

Greenwich Hospital Association, The, Greenwich, Conn.

Hahnemann Hospital, Scranton, Pa.

Halifax District Hospital, Daytona Beach, Fla.

Hamot Hospital Association, Erie, $\mathrm{Pa}$.

Harlem Valley State Hospital, Wingdale, N. Y.

Harper Hospital, Detroit, Mich.

Harrisburg State Hospital, Harrisburg, $\mathrm{Pa}$.

Healthwin Hospital, South Bend, Ind.

Henry County Hospital, New Castle, Ind.

Hettwer Bedding Co., Philadelphia, Pa.

Hewitt Restfoam Division, Hewitt-Robins, Inc., Buffalo, N. Y.

High Point Memorial Hospital, High Point, N. C.

Highland-Alameda County Hospital, Oakland, Calif.

Highland Hospital, Rochester, N. Y.

Highland Park Hospital Foundation, Highland Park, Ill.

Hospital Bureau of Standards \& Supplies, Inc., New York, N. Y.

Hospital of the Good Samaritan, Los Angeles, Calif.

Hospital of the Good Shepherd of Syracuse University, Syracuse, N. Y.

Hospital for Joint Diseases, New York, N. Y.

Hospital Purchasing Service of Pennsylvania, Philadelphia, $\mathrm{Pa}$.

Hurley Hospital, Flint, Mich.

Hyman Surgical Supply Co., Winnipeg, Manitoba, Canada.

Idaho Falls Latter Day Saints Hospital, Idaho Falls, Idaho.

Indiana University Medical Center, Indianapolis, Ind.

Iowa State Sanatorium, Oakdale, Iowa.

Iowa-State University of Iowa Hospitals, Iowa City, Iowa.

J. J. McCook Memorial Hospital, Hartford, Conn.

James Decker Munson Hospital, Traverse City, Mich.

Jamestown General Hospital, Jamestown, N. Y. Jane Lamb Memorial Hospital, Clinton, Iowa. Jewish Sanitarium \& Hospital for Chronic Diseases, Brooklyn, N. Y.

Johns Hopkins Hospital, Baltimore, Md

Kahler Corp., The, Rochester, Minn.

Kennestone Hospital, Marietta, Ga.

Kern General Hospital, Bakersfield, Calif.

Kingston Foam Rubber Products Co., Kingston, N. Y.

Laconia Hospital, Laconia, N. H.

Lafayette Home Hospital, Lafayette, Ind.

Lake County Memorial Hospital, Painesville, Ohio.

Lake County Tuberculosis Sanatorium, Waukegan, Ill.

Lakeville State Sanatorium, Middleboro, Mass.

La Mesa Community Hospital, La Mesa, Calif.

Lankenau Hospital, Philadelphia, Pa.

Lawrence General Hospital, Lawrence, Mass.

Lenox Hill Hospital, New York, N. Y.

Lima Memorial Hospital, Lima, Ohio.

Long Island College Hospital, Brooklyn, N. Y.

Los Angeles, City of, Los Angeles, Calif.

Los Angeles County General Hospital, Los Angeles, Calif.

Lutheran Deaconess Hospital, Chicago, Ill.

Lutheran Memorial Hospital of Newark, Newark, N. J.

Lynchburg General Hospital, Lynchburg, Va.

Lynn Hospital, Lynn, Mass.

Magee Hospital, Pittsburgh, $\mathbf{P a}$

Manhattan Eye, Ear \& Throat Hospital, New York, N. Y.

Mansfield General Hospital, Mansfield, Ohio.

Marcelo Rubber \& Latex Products, Inc., Malabon, Rizal, P. I.

Margaret Hague Maternity Hospital, Jersey City, N. J.

Marshall Lodge Memorial Hospital, Lynchburg, Va.
Mary Fletcher Hospital, Burlington, Vt.

Mary Hitchcock Memorial Hospital, Hanover, N. H.

Mary Imogene Bassett Hospital, Cooperstown, N. Y.

Massachusetts General Hospital, Boston, Mass.

Massachusetts Memorial Hospitals, Boston, Mass.

Massillon City Hospital, Massillon, Ohio.

Maumee Valley Hospital, Toledo, Ohio.

McPheeters Hospital, Modesto, Calif.

Memorial Hospital of DuPage County, Elmhurst, Ill.

Memorial Hospital, Roxborough, Philadelphia, $\mathrm{Pa}$.

Mendocino State Hospital, Talmage, Calif.

Mercy Hospital, Baltimore, Md.

Mercy Hospital, Bakersfield, Calif.

Mercy Hospital, Bay City, Mich.

Mercy Hospital, Urbana, Ill.

Mercy Hospital of Johnstown, Johnstown, Pa. Methodist Hospital, Madison, Wis.

Methodist Hospital, Philadelphia, $\mathrm{Pa}$.

Methodist State Hospital, Mitchell, S. Dak.

Miami Valley Hospital, Dayton, Ohio.

Michael Reese Hospital, Chicago, Ill.

Michigan State Sanatorium, Howell, Mich

Michigan-University of Michigan Hospital, Ann Arbor, Mich.

Middlesex Hospital, Middletown, Conn.

Middletown State Hospital, Middletown, N. Y. Millard Fillmore Hospital, Buffalo, N. Y.

Mills Memorial Hospital, San Mateo, Calif.

Minnesota-University of Minnesota Hospi-

tals, Minneapolis, Minn.

Miriam Hospital, Providence, R. I.

Misericordia Hospital, Philadelphia, $\mathrm{Pa}$.

Monmouth Memorial Hospital, Long Branch, N. J.

Moose Lake State Hospital, Moose Lake, Minn.

Morgan County War Memorial Hospital, Berkeley Springs, W. Va.

Morristown Memorial Hospital, Morristown, N. J.

Mount Auburn Hospital, Cambridge, Mass.

Mount Carmel Hospital, Columbus, Ohio.

Mount Sinai Hospital, Hartford, Conn.

Mount Sinai Hospital, New York, N. Y.

Mount Vernon Hospital, Mount Vernon, N. Y.

Nashville General Hospital, Nashville, Tenn.

Nathan Littauer Hospital, Gloversville, N. Y.

National Jewish Hospital at Denver, Denver, Colo.

Nebraska Orthopedic Hospital, Lincoln, Nebr.

New Castle Hospital, New Castle, $\mathrm{Pa}$.

New England Hospital, Roxbury, Mass.

New York Eye and Ear Infirmary, New York, N. Y.

New York Hospital, New York, N. Y.

New York Medical College, Flower \& Fifth Avenue Hospital, New York, N. Y.

New York Psychiatric Institute, New York, N. Y.

Newark Beth Israel Hospital, Newark, N. J.

Newark Hospital Association, Newark, Ohio.

Newton-Wellesley Hospital, Newton Lower Falls, Mass.

Niagara Falls Memorial Hospital, Niagara Falls, N. Y.

Niagara Sanatorium, Lockport, N. Y.

Norfolk County Hospital, South Braintree, Mass.

North Country Community Hospital, Glen Cove, N. Y.

North Michigan Tuberculosis Sanatorium, Gaylord, Mich.

Northern Liberties Hospital, Philadelphia, Pa Norwich State Hospital, Norwich, Conn.

Oil City Hospital, Oil City, Pa.

Oklahoma State Veterans Hospital, Sulphur, Okla.

Orange Memorial Hospital, Orange, N. J.

Orange Memorial Hospital, Orlando, Fla.

Our Lady of Mercy Hospital, Cincinnati, Ohio.

Overlook Hospital, Summit, N. J.

Passaic General Hospital, Passaic, N. J.

Passavant Hospital, Pittsburgh, $\mathrm{Pa}$. 
Paterson General Hospital, Paterson, N. J. Pennsylvania Department of Health, Tuberculosis Sanatorium, South Mountain, $\mathbf{P a}$.

Pennsylvania Hospital, Philadelphia, Pa.

Pennsylvania State Sanatorium for Tuberculosis No. 3, Hamburg, Pa.

Peter Bent Brigham Hospital, Boston, Mass.

Phoenix Medical Center, Phoenix, Ariz.

Pima County General Hospital, Tucson, Ariz.

Portland Sanitarium \& Hospital, Portland, Oreg.

Presbyterian Hospital, Denver, Colo.

Presbyterian Hospital, Pittsburgh, Pa.

Princeton Hospital, Princeton, N. J.

Providence Hospital, Detroit, Mich.

Providence Memorial Hospital, El Paso, Tex.

Provident Hospital \& Training School, Chicago, Ill.

Queen's Hospital, Honolulu, T. H.

Quincy City Hospital, Quincy, Mass.

Reid Memorial Hospital, Richmond, Ind.

Retreat State Hospital, Retreat, $\mathbf{P a}$.

Río Piedras Tuberculosis Hospital, Río Piedras, P. R.

Riverview Hospital, Wisconsin Rapids, Wis.

Robert Packer Hospital, Sayre, Pa.

Roger Williams General Hospital, Providence, R. I.

Roosevelt Hospital, New York, N. Y.

Sacred Heart Hospital, Allentown, $\mathbf{P a}$.

St. Alphonsus Hospital, Boise, Idaho.

St. Elizabeth's Hospital, Brighton, Mass.

St. Francis Hospital, Honolulu, T. H.

St. Francis Hospital, Inc., Miami Beach, Fla.

St. Francis Xavier Infirmary, Charleston, S. C.

St. Joseph Hospital, Lexington, Ky.

St. Joseph Hospital, Orange, Calif.

St. Lucas Deaconess Hospital, Faribault, Minn.

St. Luke's Hospital, Chicago, Ill.

St. Luke's Hospital, Cleveland, Ohio.

St. Luke's Hospital, Davenport, Iowa.

St. Luke's Hospital, Milwaukee, Wis.

St. Luke's Hospital, Newburgh, N. Y.

St. Luke's Hospital, Racine, Wis.

St. Luke's Hospital, St. Louis, Mo.

St. Margaret's Hospital, Kansas City, Kans.

St. Mary's Hospital, Green Bay, Wis.

St. Peter Hospital, Olympia, Wash.

St. Thomas Hospital, Akron, Ohio.

St. Vincent Hospital, Billings, Mont.

St. Vincent's Hospital, Indianapolis, Ind.

St. Vincent's Hospital, Philadelphia, Pa.

St. Vincent's Hospital, Portland, Oreg.

St. Vincent's Infirmary, Little Rock, Ark.

Salinas Valley Memorial Hospital District, Salinas, Calif.

San Diego County General Hospital, San Diego, Calif.

Sears, Roebuck \& Co., Chicago, Ill.

Seaside Memorial Hospital, Long Beach, Calif.

Seattle, City of, Seattle, Wash.

Sewickley Valley Hospital, Sewickley, $\mathrm{Pa}$

Shawnee Indian Sanatorium, Shawnee, Okla.
Sheppard \& Enoch Pratt Hospital, Towson, Md.

Sisters' Hospital, Waterville, Maine.

Sleepmaster Products Co., Inc., Newark, N. J. Soldiers' Home in Massachusetts, Chelsea, Mass.

Somerset City Hospital, Somerset, Ky.

South Nassau Communities Hospital, Rockville Centre, N. Y.

South San Francisco Hospital, South San Francisco, Calif.

South Shore Hospital, South Weymouth, Mass.

Southern Pacific General Hospital, San Francisco, Calif.

Sparks Memorial Hospital, Fort Smith, Ark.

Sponge Rubber Products Co., The, Shelton, Conn.

Staten Island Hospital, New York, N. Y.

Strong Memorial Hospital, Rochester, N. Y.

Sunny Acres Cuyahoga County Tuberculosis Hospital, Cleveland, Ohio.

Sutter Hospitals of Sacramento, Sacramento, Calif.

Swedish Hospital, Seattle, Wash.

Syracuse Memorial Hospital, Syracuse, N. Y.

Tampa Municipal Hospital, Tampa, Fla.

Theda Clark Memorial Hospital, Neenah, Wis.

Tompkins County Memorial Hospital, Ithaca, N. Y.

Truesdale Hospital, Inc., Fall River, Mass.

Trumbull Memorial Hospital, Warren, Ohio.

Tuberculosis League Hospital, Pittsburgh, $\mathbf{P a}$

United States Rubber Co., Mishawaka, Ind.

United States Testing Co., Inc., Hoboken, N. J.

Virginia, University of, Charlottesville, Va.

Warren A. Candler Hospital, Savannah, Ga.

Washington County Hospital, Hagerstown, Md.

Waterbury Hospital, Waterbury, Conn.

Watts Hospital, Durham, N. C.

Waverly Hills Tuberculosis Sanatorium, Waverly Hills, Ky.

Wayne County General Hospital, Eloise, Mich.

Weid County Hospital, Greeley, Colo.

Wesley Memorial Hospital, Chicago, Ill.

Westfield State Sanatorium, Westfield, Mass.

White Plains Hospital Association, White Plains, N. Y.

Wichita General Hospital, Wichita Falls, Tex.

Will Corp., Rochester, N. Y.

Wills Eye Hospital, Philadelphia, $\mathrm{Pa}$

Woman's Hospital in the State of New York, New York, N. Y.

Woonsocket Hospital, Woonsocket, R. I.

\section{U. S. GOVERNMENT AGENCIES}

Agriculture, U. S. Department of, Division of Procurement and Property Management.

Army Medical Center.

Army, U. S. Department of, Office of the Assistant Chief of Staff.

Public Health Service, Bureau of Medical Services. 


\section{ACCEPTANCE OF COMMERCIAL STANDARD}

If acceptance has not previously been filed, this sheet properly filled in, signed, and returned will provide for the recording of your organization as an acceptor of this commercial standard.

Date

Commodity Standards Division, Office of Industry and Commerce,

U. S. Department of Commerce,

Washington 25, D. C.

Gentlemen :

We believe that this Commercial Standard constitutes a useful standard of practice, and we individually plan to utilize it as far as practicable in the

\section{$\begin{array}{llll}\text { Production }^{1} & \text { Distribution }^{1} & \text { Purchase }^{1} & \text { Testing }^{1}\end{array}$}

of latex foam mattresses for hospitals.

We reserve the right to depart from it as we deem advisable.

We understand, of course, that only those articles which actually comply with the standard in all respects can be identified or labeled as conforming thereto.

Signature of authorized officer

$$
\text { (In ink) }
$$

(Kindly typewrite or print the following lines)

Name and title of above officer

Organization

Street address

City, zone, and State

1 Underscore which one. Please see that separate acceptances are filed for all subsidiary companies and affiliates which should be listed separately as acceptors. In the case of related interests, trade associations, trade papers, etc., desiring to record their general support, the words "General support" should be added after the signature. 


\section{TO THE ACCEPTOR}

The following statements answer the usual questions arising in connection with the acceptance and its significance:

1. Enforcement.-Commercial standards are commodity specifications voluntarily established by mutual consent of those concerned. They present a common basis of understanding between the producer, distributor, and consumer and should not be confused with any plan of governmental regulation or control. The United States Department of Commerce has no regulatory power in the enforcement of their provisions, but since they represent the will of the interested groups as a whole, their provisions through usage soon become established as trade customs, and are made effective through incorporation into sales contracts by means of labels, invoices, and the like.

2. The acceptor's responsibility.-The purpose of commercial standards is to establish, for specific commodities, nationally recognized grades or consumer criteria, and the benefits therefrom will be measurable in direct proportion to their general recognition and actual use. Instances will occur when it may be necessary to deviate from the standard and the signing of an acceptance does not preclude such departures; however, such signature indicates an intention to follow the commercial standard, where practicable, in the production, distribution, or consumption of the article in question.

3. The Department's responsibility.-The major function performed by the Department of Commerce in the voluntary establishment of commercial standards on a Nation-wide basis is fourfold: first, to act as an unbiased coordinator to bring all interested parties together for the mutually satisfactory adjustment of trade standards; second, to supply such assistance and advice as past experience with similar programs may suggest; third, to canvass and record the extent of acceptance and adherence to the standard on the part of producers, distributors, and users; and fourth, after acceptance, to publish and promulgate the standard for the information and guidance of buyers and sellers of the commodity.

4. Announcement and promulgation.-When the standard has been endorsed by a satisfactory majority of production or consumption in the absence of active, valid opposition, the success of the project is announced. If, however, in the opinion of the standing committee or of the Department of Commerce, the support of any standard is inadequate, the right is reserved to withhold promulgation and publication. 
COMMERCIAL STANDARDS

CS No.

0. Commercial standards and their value to business.

1. Clinical thermometers.

2. Mopsticks.

3. Stoddard solvent.

4. Staple porcelain (all-clay) plumbing fixtures.

5. Pipe nipples; brass, copper, steel and wrought-iron.

6. Wrought-iron pipe nipples. Superseded by CS5.

7. Standard weight malleable iron or steel screwed unions.

8. Gage blanks.

9. Builders' template hardware.

10. Brass pipe nipples. Superseded by CS5.

11. Moisture regains of cotton yarns.

12. Fuel oils.

13. Dress patterns.

14. Bors' sport and dress shirt (woven fabrics) size measurements.

15. Men's pajama sizes (made from woven fabries).

16. Wallpaper.

17. Diamond core drill fittings.

18. Hickory golf shafts.

19. Foundry patterns of wood

20. Vitreous china plumbing fixtures.

21. Interchangeable ground-glass joints, stopcocks, and stoppers.

22. Builders' hardware (nontemplate).

23. Feldspar.

24. Screw tlureads and tap-drill sizes.

25. Special screw threads. Superseded by CS24.

26. Aromatic red cedar closet lining.

27. Mirrors.

28. Cotton fabric tents, tarpaulins and covers.

29. Staple seats for water-closet bowls.

30. (Withdrawn.)

31. Wood shingles.

32. Cotton clotl for rubber and pyroxylin coating.

33. Knit underwear (exclusive of rayon)

34. Bag, case, and strap leather.

35. Hardwood plywood.

36. Fourdrinier wire cloth.

37. Steel bone plates and serews.

3S. Hospital rubber sheeting.

39. (Withdrawn.)

40. Surgeons' rubber gloves.

41. Surgeons latex gloves.

42. Structural fiber insulating board

43. Grading of sulphonated oils.

44. Apple wraps.

45. Douglas fir plywood.

46. Hosiery lengths and sizes.

47. Marking of gold-filled and rolled-soldplate articles other than vatehcises.

48. Domestic burners for Penusslvania anthracite (underfeed type).

49. Chip board, laminated chip board, and miscellaneous boards for bookbinding purposes.

50. Binders board for bookbinding and other purposes.

51. Marking articles made of silver in combination with gold.

52. Mohair pile fabrics (100-percent mohair plain velvet, 100 -percent mohair plain frieze, and 50-percent mohair plain frieze)

53. Colors and finishes for cast stone.

54. Mattresses for hospitals.

55. Mattresses for institutions.

56. Oak flooring.

57. Book cloths, buckrams, and impregnated fabrics for bookbinding purposes except library bindings.

58. Woven elastic fabrics for use in overalls (overall elastic webbing).

59. Textiles-testing and reporting.

60. Hardwood dimension lumber.
So.

61. Venetian blinds (grade A, custommade).

62. Colors for kitchen accessories.

63. Colors for bathroom accessories.

64. Walnut veneers.

65. Methods of analysis and of reporting fiber composition of textile prorlucts.

66. Marking of articles made wholly or in part of platinum.

67. Marking articles made of karat gold.

68. Liquid hypochlorite disinfectant, deodorant, and germicide.

69. Pine oil disinfectant

70. Phenolic disinfectant (emulsifying type) (published with CS71).

71. Phenolic disinfectant (soluble type) (published witl CS70).

72. Houselold insecticide (liquid spray type).

73. Old growth Douglas fir, Sitka spruce and western hemlock standard stock doors.

74. Solid hardwood wall panelin:

75. Automatic mechanical draft oil burners designed for domestic installations.

76. Hardwood interior trim and molding.

77. Enameled cast-iron plumbing fixtures.

78. Ground-and-polished leuses for sum glasses (published with CS79).

79. Blown, drawn, and dropped lenses fo: sun glasses (published with CS78).

80. Electric direction sional systems other than semaphore type for commercial and other vehicles subject to snecial motor vehicle laws (after market).

81. Adverse-weather lamps for vehicles (after market).

82. Inner-controlled spotlamps for vehicles (after market).

83. Clearance, marker, and identification lamps for vehicles (after market).

84. Electric tail lamps for vehicles (after market).

85. Electric license-plate lamps for vehicles (after market).

86. Electric stop lamps for vehicles (after market).

87. Red electric warning lanterns.

88. Liquid burning flares.

89. Hardwood stair treads and risers.

90. Power cranes and shovels.

91. Factory-fitted Douglas fir entrance doors.

92. Cedar, cypress, and redwood tank stock lumber.

93. Portable electric drills (exclusive of high frequency).

94. Calking lead.

95. Lead pipe.

96. Lead traps and bends.

97. Electric supplementary driving and passing lamps for vehicles (after market).

98. Artists' oil paints.

99. Gas floor furnaces-gravity circulating type.

100. Porcelain-enameled steel utensils.

101. Flue-connected oil-burning space heaters equipped with vaporizing pot-type burners.

102. (Reserved for "Diesel and fuel-oil engines.")

103. Rayon jacquard velour (with or without other decorative yaru).

104. Warm-air furnaces equipped with vaporizingtype oil burners.

105. Mineral wool insulation for low temperatures.

106. Boys' pajama sizes (woven fabries).

107. (Withdrawn.)

108. Treading automobile and truck tires.

109. Solid-fuel-burning forced-air furnaces 
CS No.

110. Tire repairs-rulcanized (passenger, truck, and bus tires).

111. Earthenware (vitreous-glazed) plumbing fixtures.

112. Homogeneous fiber wallboard.

113. Oil-burning floor furnaces equipped witl vaporizing pot-type burners.

11t. IIospital sheeting for mattress protec tion.

115. Porcelain-enameled tanks for domestic use.

116. Bituminized-fibre drain and sewer pipe.

117. Mineral wool insulation for heated in dustrial equipment.

118. Marking of jewelry and novelties of silver.

(E) 119.1 Dial indicators (for linear measurements ).

120. Standard stock ponderosa pine doors.

121. Women's slip sizes (woren fabrics).

122. Western softwood plywood.

12:. Grading of diamond powder.

(E) 124.1 Master disks.

125. Prefabricated homes.

126. Tank-mounted air compressors.

127. Self-contained mechanically refrigerated drinking water coolers.

128. Men's sport shirt sizes-woven fabrics (other than those marked with regular neckband sizes).

129. Materials for safety wearing apparel.

130. Color materials for art education is schools.

131. Industrial mineral wool products, all types-testing and reporting.

132. Hardware cloth.

133. Woven wire netting.

134. Cast aluminum cooking utensils (metal composition).

135. Men's shirt sizes (exclusive of work shirts).

136. Blankets for hospitals (wool, and wool and cotton)

137. Size measurements for men's and boys' shorts (woven fabrics).

138. Insect wire screening

139. Work gloves.

140. Testing and rating convectors.

141. Sine bars, blocks, plates, and fixtures.

142. Automotive lifts.

143. Standard strength and extra strengtl perforated clay pipe.

144. Formed metal porcelain enameled sanitary ware.

145. Testing and rating hand-fired lot-water supply boilers.

146. Gowns for hospital patients.

147. Colors for molded urea plastics.

148. Men's circular flat- and rib-knit rayon underwear.

149. Utility type house dress sizes.

150. Hot rolled rail steel bar's (produced from tee-section rails).
CS No.

151. Body measurements for the sizing of apparel for infants, babies, toddlers, and children (for the knit underwear industry ).

152. Copper naphthenate wood-preservative (spray, brush, dip application).

153. Body measurements for the sizing of apparel for girls (for the knit underwear industry)

154. (Reserved for "Wire rope.")

155. Body measurements for the sizing of boys' apparel (knit underwear, shirts, trousers)

156. Colors for polystyrene plastics.

157. Ponderosa pine and sugar pine plywood.

158. Model forms for girls' apparel.

159. Sun glass lenses made of ground and polished plate glass, thereafter thermally curved.

160. Wood-fiber blanket insulation (for building construction)

161. "Standard grade" hot-dipped galvan ized ware (coated after fabrication).

162. Tufted bedspreads.

163. Standard stock ponderosa pine windows, sash and screens.

164. (Reserved for "Concrete mixer's.")

165. Zinc naphthenate wood-preservative (spray, brush, dip application).

166. Size measurements for men's work trousers.

167. Automotive and general service copper tube.

168. Polystyrene plastic wall tiles, and adhesives for their application.

169. Galvanized ware fabricated from $p r c$ galvanized steel sheets.

170. Cotton flour-bag (sack) towels.

171. Hardwood veneered doors.

172. Brass trim for water-closet bowls, tanks, and urinals (dimensiona standards).

173. Heavy-duty alpha-cellulose-filled melamine tableware.

174. 140-F dry-cleaning solvent.

175. Circular-knitted gloves and mittens.

176. Prefinished wall panels.

177. Bituminous-coated metal septic tanks (single compartment, residential).

178. Testing and rating ventilating fans (axial and propeller types).

179. Installation of attic ventilation fans in residences.

180. Model forms for boys' apparel.

181. (Reserved.)

182. Latex foam mattresses for hospitals.

183. Boys' trouser size measurements.

184. Steel fence posts-field and line type (produced from lot-rolled steel sections).

185. Wool felt.

Notice.-Those interested in commercial standards with a view toward accepting them as a basis of everyday practice may secure copies of the above standards, while the supply lasts, by addressing the Commodity Standards Division, Office of Industry and Commerce, U. S. Department of Commerce, Washington 25. D. C.

I Where "(F)" precedes the CS number, it indicates an emergeney commercial standard, drafted under war conditions with a view toward early revision. 